\title{
Strategies of professional development for EFL and technology teachers
}

\author{
Mohamed Soliman Abou Shoqair ${ }^{1}$, Sumer Salman Abou Shaaban ${ }^{2}$ \\ ${ }^{1}$ College of Education, The Islamic University of Gaza (IUG), Palestine \\ ${ }^{2}$ Assistant Professor of e-Learning and TEFL, Al-Azhar University - Gaza \\ Email address: \\ mshgair@iugaza.edu.ps (M. S. A. Shoqair), s.aboushaaban@alazhar.edu.ps(S. S. A. Shaaban)
}

To cite this article:

Mohamed Soliman Abou Shoqair, Sumer Salman Abou Shaaban. Strategies of Professional Development for EFL and Technology Teachers. Education Journal. Vol. 2, No. 6, 2013, pp. 249-255. doi: 10.11648/j.edu.20130206.17

\begin{abstract}
This research aims at showing the most common strategies of professional development for EFL and technology teachers and revealing if the specialty, gender and academic levels affect adaptation of these strategies. The descriptive analytical method was followed in this research. A questionnaire including a list of (20) strategies of professional development was prepared. All EFL and technology teachers in the Gaza Strip governmental schools completed the questionnaire which consisted of (675) teachers. Frequencies, means, standard deviation, percentage, T- test and One Way ANOVA were used to analyse the data statistically. The results revealed that: Conducting action research continually, using social networks (Twitter, Facebook, and others) in exchanging viewpoints and experiences, and participating in educational e-forums were the most common strategies because they recorded high percentages of teachers' responses.
\end{abstract}

Keywords: Strategies, Professional Development, EFL Teachers, Technology Teachers

\section{Introduction}

Most educational programs seek to prepare teachers who are able to keep abreast with academic and educational resources and who have their own strategies of professional development as lifelong learning in order to be successful teachers who can meet $21^{\text {st }}$ century requirements. Rodrigues (2005a, p.4) mentioned that "professional development has no fixed route and real end if it is viewed as lifelong learning and providing the professional continues to work in the profession and is keen to be the best professional they can be." By adopting professional development resources and strategies they will learn a lot about successful practices and implementation of instructional strategies and technology in their classrooms (National Staff Development Council, 2001, p.3). Rodrigues (2005b, p.1) added "professional development has had to keep pace, in order to provide teachers with an opportunity to develop skills and experiences."

Moreover, following different strategies of professional development helps teachers to understand the general cognitive and social/emotional characteristics of students. Those strategies provide different techniques for tapping the unique learning strengths of each student. Besides that, they enhance teachers to use knowledge of their students' interests and backgrounds to assist them in planning meaningful and relevant lessons (National StaffDevelopment Council, 2001, p.10).

Rodrigues (2005a, p.1) said that "most teachers are concerned about their personal professional development, and a consequence we see large numbers of teachers attending various professional development programs." To get the fruitful benefit of adopting professional development strategies, teachers should have four types of awareness which are technical, personal, problematic and critical (Diaz-Maggioli, 2004, p.15).

Patricia and Rhoton (2001, p. 15) advised teachers to consider five elements carefully in designing their professional development programs. These elements are:

- Determine self goals and desired outcomes

- Lay out a plan

- $\quad$ Specify a time line for the plan

- Reflect and evaluate each process

- Make improvements.

These elements emphasize that "designing professional development is strategic, thoughtful work and simply a 
matter of always offering what is easiest, most expedient, or most attractive at the moment" (ibid, p. 15).

Banks et al (2001, pp 4-8) mentioned that the Association for Science Education classifies some areas for professional development to be considered by teachers. These areas are:

1- Subject knowledge and understanding.

2- Development of teaching and assessment skills

3- Understanding teaching and learning

4- The wider curriculum and other changes affecting teaching

5- Management skills: managing people

6- Management skills: managing yourself and your professional development.

Despite the urgent need of teachers' professional development, most strategies are constricted by some obstacles. These obstacles hinder teachers to practice different strategies of professional development and keep continual development. Diaz-Maggioli (2004, pp. 2-4) asked teachers to be aware of the following obstacles:

1- Top-down decision making,

2- The idea that teachers need to be fixed,

3- Lack of ownership of the professional development process and its results,

4- The technocratic nature of professional development content,

5- Universal application of classroom practices regardless of subject, student age, or level cognitive development;

6- Lack of variety in delivery modes of professional development,

7- Inaccessibility of professional development opportunities,

8- Little or no support in transferring professional development ideas to the classroom,

9- Standardized approaches to professional development that disregard the varied needs and experiences of teachers,

10- Lack of systematic evaluation of professional development, and

11- Llittle or no acknowledgment of the learning characteristics of teachers among professional development planners.

As a matter of fact, the topic of teachers' professional development has a widespread concern among researchers. Below are some previous related studies: de Vries and van de Grift (2013) investigated the relationship between teachers' continuing professional development (CPD) and their beliefs about learning and teaching, in a Dutch secondary education context. A cluster analysis produced three distinctive CPD profiles, reflecting relatively low, medium, and high participation in the three CPD activities. The greater teachers' participation in CPD, the more student oriented those teachers are. These findings have strong implications for fostering teachers' participation in CPD and encouraging their student orientation.

Liu (2012) investigated the application of an online videocase discussion community into fostering preservice and inservice EFL teachers' professional development in Taiwan. The findings showed that the preservice and inservice teachers appeared respectively to play different roles in discussing teaching videocases online. Yet, what they noticed in the teaching events shifted from diverse to similar focuses after engaging in online videocase discussion for almost one year.

Atwan and Al-Faleet (2010) viewed the reality of self professional development and its obstacles for technology teachers in Gaza Governorates Schools. The study results included that the practice degree of technology teachers for methods of self professional development was $(76 \%)$. The technological knowledge acquisition came first in practice for technology teachers followed by participation in scientific events, while using the internet was their last choice. According to the viewpoint of technology teachers, administrative obstacles were much stronger than self obstacles.

Granshaw (2010) examined the nature and characteristics of effective professional development for technology teachers. The conclusion of the interview data indicated that there is a wide range of characteristics which may be considered effective for technology teachers, foremostly the opportunity for them to work collaboratively in examining programs, student work, resources and exemplars, such that teachers can build on their existing knowledge and skills which is most effective for them. The development of pedagogical content knowledge and subject content knowledge enabled the teachers to construct new understandings of teaching and student learning processes in technology education.

Halim (2008) revealed the effect of a training program based on three professional development strategies; namely: action learning, peer coaching, and study group on improving teaching performance of the faculty of education at Helwan University EFL student-teachers in the light of standards for teachers of English pre-service. The results showed that there were significant differences between the mean scores of the EFL student-teachers on the achievement test and the scoring rubric in favor of the post test mean scores due to the effect of the professional development strategies based program.

Kesti (2008) built a conception of self professional development for English language teachers of girls public schools based on realization and contemporaneous trends. The results indicated that: the concept of self Professional development is clear for $(78.4 \%)$ of the supervisors, and for half $(50 \%)$ of the teachers. According to the English teachers and their supervisors, the practices of self professional development used by ELT are: (training programs, and in medium percentage, reading books, journals, and electronic publications). According to the English teachers and their supervisors, the barriers of self Professional development are: (class load, abundant responsibilities, numerous students, absence of model lessons, training programs and workshops, and lack of 
courage on part of the teachers).

Baran and Cagiltay (2006) viewed teachers' opinions on traditional professional development courses and their experiences from an online course. The researchers based on presenting qualitative results by asking (10) teachers from a private school to participate in an online professional development course. They generally emphasized the lack of practice in both traditional and online PD courses. Further, abundance of theoretical concepts and context independent examples are determined as other problems. They proposed that PD programs should be developed together by both academician and expert teacher.

Torff, Sessions and Byrnes (2005) assessed teachers' beliefs about professional development initiatives. A scale for assessing teachers' beliefs was developed and the researchers ensured its reliability and validity. Results indicated that the teachers' attitudes about the professional development scale produced scores with high reliability, a stable one-factor structure, and satisfactory construct and discriminate validity.

\subsection{Research Problem}

Although the faculties of education try to provide student-teachers with most of the needed teaching skills and the Ministry of Education continues to conduct professional development training courses for all teachers, the need for adopting different self professional development strategies is highly urged due to the characteristics and needs of the current era. Weakness of teachers in following-up new trends in teaching and updating their knowledge in their specialization remains to be the most important factors that affect their performance inside the classrooms as noted by several supervisors.

\subsection{Research Question}

What are the most common strategies of professional development for EFL and technology teachers?

\subsection{Research Hypotheses}

The researcher addressed the following hypotheses:

1. There are statistically significant differences at $(\alpha \leq$ 0.05) between the strategies of teachers' professional development due to specialty (EFL and Technology)

2. There are statistically significant differences at $(\alpha \leq$ 0.05) between the strategies of teachers' professional development due to gender (male and female).

3. There are statistically significant differences at $(\alpha \leq$ 0.05) between the strategies of teachers' professional development due to academic level (Bachelor degree, Master, and Ph D).

\subsection{Research Purposes}

This research aims at achieving the following purposes:
1. Find out the most common strategies of professional development that teachers of EFL and technology already practise, and

2. Investigate if there are/are not statistically significant differences at $(\alpha \leq 0.05)$ between strategies of teachers' professional development due to specialty, gender, and academic level.

\subsection{Research Significant}

This research shows some strategies of teachers' professional development that could help many teachers and student-teachers to develop themselves professionally.

In addition, the current study is expected to encourage the researchers to deal with the obstacles and challenges of professional development strategies. It could also motivate supervisors to create professional development training courses based on the mentioned strategies.

\subsection{Delimitations of the Study}

The study focuses to reveal the strategies of professional development among all EFL and technology teachers at the Gaza Strip governmental school in the academic year 2012/ 2013.

\subsection{Definition of Terms}

The following definitions are developed by the researchers operationally to remove any ambiguity in understanding these terms through the research.

Strategies are the various information resources conducted by the teachers to gather needed educational information, discuss educational issues or see application of educational teaching/learning strategies.

Professional development is an ongoing process of learning by using multiple educational sources for the teachers to improve their performance, to keep their competencies up-to-date and to achieve the objectives of the teaching/learning process successfully.

EFL Teachers are the teachers who teach English as a foreign language at the Gaza Strip governmental schools.

Technology Teachers are the teachers who teach technology subject for Palestinian students at the Gaza Strip governmental schools.

\section{Methods}

The following procedures were followed to answer research questions:

\subsection{Research Design}

The researchers used the descriptive analytical method because the purpose of this study is to explore the most common strategies of professional development followed by EFL and technology teachers at the Gaza Strip governmental schools. 


\subsection{Research Population and Sample}

The population of this study consisted of all teachers (males and females) who teach EFL and technology at the Gaza Strip schools. The study population included (675) among which (326) were male teachers and (349) female. There were (581) English language teachers and (94) technology teachers. All teachers in the population of the study were asked to complete the questionnaire as a survey sample.

\subsection{Tool of the Study}

A questionnaire including twenty strategies of professional development was prepared. The teachers were asked to choose one of two answers: "yes, I use" or "no, I do not use". If they use the strategies; then, they should determine the degree of the use by selecting one from three options Likart-scale (always, sometimes, and rarely).

\subsection{Validity of the Questionnaire}

To ensure the consistency of the questionnaire two methods of measuring reliability which are juries' validity and internal consistency were used as follows:

\subsection{Juries Validity}

The questionnaire waspresentedtoa group of expertsin order toimproveitandto givetheiropinionon. The researchersmodifiedtheofsomephrasesanddeletedsome of them inlightofthejuries' views.

\subsection{Internal Consistency}

To verify the internal consistency of the questionnaire, the Pearson correlation coefficient between the degree of each strategy and the total degree of the questionnaire was measured. The following table outlines the results.

Table (1). Pearson Correlation between the Score of each Item and the Total Score of the Questionnaire

\begin{tabular}{|c|c|c|c|}
\hline $\mathbf{N}$ & Strategies of Professional Development & Correlation & Sig. \\
\hline 1 & Attending educational lectures & $.591^{* *}$ & .000 \\
\hline 2 & Participating in academic activities (conferences, workshops, educational magazines) & $.631^{* *}$ & .000 \\
\hline 3 & Watching videos on YouTube related to educational applications & $.621^{* *}$ & .000 \\
\hline 4 & Reading different educational articles and researches & $.658^{* *}$ & .000 \\
\hline 5 & Participating in discussion groups with colleagues in school & $.566^{* *}$ & .000 \\
\hline 6 & Depending on self reflection based on my standards & $.506^{* *}$ & .000 \\
\hline 7 & Depending on self reflection based on international standards (standards check list) & $.601^{* *}$ & .000 \\
\hline 8 & Considering reports of exchange visits & $.596^{* *}$ & .000 \\
\hline 9 & Asking my students for feedback & $.558^{* *}$ & .000 \\
\hline 10 & Consulting experts of education & $.646^{* *}$ & .000 \\
\hline 11 & Taking advantages of supervisors' feedback & $.502^{* *}$ & .000 \\
\hline 12 & Taking advantages of principle's feedback & $.511^{* *}$ & .000 \\
\hline 13 & Using social networks (Twitter, Facebook, and others) in exchanging viewpoints and experiences & $.639^{* *}$ & .000 \\
\hline 14 & Participating in educational e-forums & $.628^{* *}$ & .000 \\
\hline 15 & Following TV or radio educational programs & $.684^{* *}$ & .000 \\
\hline 16 & Conducting action research continually & $.637^{* *}$ & .000 \\
\hline 17 & Joining various training courses & $.672^{* *}$ & .000 \\
\hline 18 & Preparing a portfolio for each curriculum I teach & $.638^{* *}$ & .000 \\
\hline 19 & Participating in peer coaching sessions & $.660^{* *}$ & .000 \\
\hline 20 & $\begin{array}{l}\text { Participating in designing educational programs (enrichment programs, remedial, curricula and extra curricula } \\
\text { activities) }\end{array}$ & $.591^{* *}$ & .000 \\
\hline
\end{tabular}


Out of the data that was explained in table (1) all values of correlation coefficient for all strategies were significant at $(0.05)$ which proves that the tool is of high internal validity.

\subsection{Reliability of the Questionnaire}

The reliability was calculated by using Cronbach Alpha. It was (0.91) which refers to a high level of reliability. Guttman Split-Half Coefficient was also used to ensure the reliability of the questionnaire and it was (0.85) which means that the tool has a high level of reliability.

\section{Findings}

Results of the most Common Strategies of Professional Development Followed by EFL and Technology Teachers

The questionnaire was completed by the teachers of EFL and technology to know the most common strategies of professional development followed by them. The results of the statistical analysis are presented in the table below:

Table (2).Total Responses, Mean, Standard Deviation, Percentage and Rank of each Strategy

\begin{tabular}{|c|c|c|c|c|c|c|}
\hline N. & Strategies of Professional Development & $\begin{array}{l}\text { Total } \\
\text { Responses }\end{array}$ & $\begin{array}{l}\text { Mean of } \\
\text { Responses }\end{array}$ & $\begin{array}{l}\text { Standard } \\
\text { Deviation }\end{array}$ & Percentage & Rank \\
\hline 1 & Attending educational lectures & 1009 & 1.49 & .666 & 37.370 & 17 \\
\hline 2 & $\begin{array}{l}\text { Participating in academic activities (conferences, } \\
\text { workshops, educational magazines) }\end{array}$ & 1204 & 1.78 & .739 & 44.592 & 10 \\
\hline 3 & $\begin{array}{l}\text { Watching videos on YouTube related to educational } \\
\text { applications }\end{array}$ & 1261 & 1.87 & .825 & 46.703 & 7 \\
\hline 4 & Reading different educational articles and researches & 1212 & 1.80 & .733 & 44.888 & 9 \\
\hline 5 & Participating in discussion groups with colleagues in school & 981 & 1.45 & .637 & 36.333 & 18 \\
\hline 6 & Depending on self reflection based on my standards & 1034 & 1.53 & .676 & 38.296 & 15 \\
\hline 7 & $\begin{array}{l}\text { Depending on self reflection based on international } \\
\text { standards (standards check list) }\end{array}$ & 1111 & 1.65 & .719 & 41.148 & 13 \\
\hline 8 & Considering reports of exchange visits & 1035 & 1.53 & .710 & 38.333 & 14 \\
\hline 9 & Asking my students for feedback & 1160 & 1.72 & .765 & 42.962 & 12 \\
\hline 10 & Consulting experts of education & 1287 & 1.91 & .811 & 47.666 & 5 \\
\hline 11 & Taking advantages of supervisors' feedback & 940 & 1.39 & .650 & 34.814 & 19 \\
\hline 12 & Taking advantages of principle's feedback & 1003 & 1.49 & .725 & 37.148 & 18 \\
\hline 13 & $\begin{array}{l}\text { Using social networks (Twitter, Facebook, and others) in } \\
\text { exchanging viewpoints and experiences }\end{array}$ & 1455 & 2.16 & 1.022 & 53.888 & 2 \\
\hline 14 & Participating in educational e-forums & 1432 & 2.12 & .967 & 53.037 & 3 \\
\hline 15 & Following TV or radio educational programs & 1306 & 1.93 & .822 & 48.370 & 4 \\
\hline 16 & Conducting action research continually & 1647 & 2.44 & .988 & 61 & 1 \\
\hline 17 & Joining various training courses & 1182 & 1.75 & .771 & 43.777 & 11 \\
\hline 18 & Preparing a portfolio for each curriculum I teach & 1234 & 1.83 & .853 & 45.703 & 8 \\
\hline 19 & Participating in peer coaching sessions & 1269 & 1.88 & .813 & 47 & 6 \\
\hline \multirow[t]{2}{*}{20} & $\begin{array}{l}\text { Participating in designing educational programs (enrichment } \\
\text { programs, remedial, curricula and extra curricula activities) }\end{array}$ & 1034 & 1.53 & .702 & 38.296 & 15 \\
\hline & Total & 23796 & 35.253 & 9.525 & 44.066 & \\
\hline
\end{tabular}

As it is clear in table (2), the most common strategies of professional development followed by teachers are: conducting action research continually, using social networks (Twitter, Facebook, and others) in exchanging viewpoints and experiences and participating in educational e-forums. They come first in terms of recording the highest percentages of teachers' responses. The results do not resemble the finding of Atwan and Al-Faleet's (2010) study, yet they do resemble the finding of Hslim's (2008) and Kesti's (2008) studies 
On the other hand, the least common strategies of professional development followed by teachers are: taking advantages of supervisors' and principle's feedback and participating in discussion groups with colleagues in school.

Results of the First Hypothesis which is "there are statistically significant differences at $(\alpha \leq 0.05)$ between the strategies of teachers' professional development due to specialty (EFL and Technology)"

Table (3).T-test Value and Significant Level between the Strategies of EFL and Technology Teachers' Professional Development

\begin{tabular}{cccccc}
\hline Specialty & No. & Means & $\begin{array}{c}\text { Standard } \\
\text { Deviation }\end{array}$ & T-test & Sig. \\
\hline English & 581 & 35.1738 & 9.78752 & .539 & .590 \\
Technology & 94 & 35.7447 & 7.73615 & & \\
\hline
\end{tabular}

Table (3) showed that the sig. value equals (.539) and it is less than (.05). This means that there are no statistically significant differences between the strategies of teachers' professional development due to specialty (EFL and Technology).

Results of the Second Hypothesis: "There are statistically significant differences at $(\alpha \leq 0.05)$ between the strategies of teachers' professional development due to gender (male and female)".

Table (4).T-test Value and Significant Level between the Strategies of Male and Female Teachers' Professional Development

\begin{tabular}{cccccc}
\hline Gender & No. & Means & $\begin{array}{l}\text { Standard } \\
\text { Deviation }\end{array}$ & T-test & Sig. \\
\hline Male & 326 & 34.4509 & 10.62750 & -2.121 & .034 \\
Female & 349 & 36.0029 & 8.31164 & & \\
\hline
\end{tabular}

Table (4) revealed that the mean of male teachers' responses is less than the mean of female responses. The sig. value equals (.034) and is larger than (0.05). This result revealed that there are statistically significant differences at $(\alpha \leq 0.05)$ between the strategies of teachers' professional development due to gender in favor of females.

Results of the Third Hypothesis: "There are statistically significant differences at $(\alpha \leq 0.05)$ between the strategies of teachers' professional development due to academic level (Bachelor degree, Master, and Ph D)".

Table (5).One-Way ANOVA Value and Significant Level among the Strategies of Bachelor degree, Master, and Ph D Teachers' Professional Development

\begin{tabular}{cccccc}
\hline & $\begin{array}{c}\text { Sum of } \\
\text { Squares }\end{array}$ & df & $\begin{array}{c}\text { Mean } \\
\text { Square }\end{array}$ & F & Sig. \\
\hline Between & & & & & \\
Groups & 4.913 & 2 & & & \\
Within & 60728.552 & 666 & 2.456 & .027 & .973 \\
Groups & 60733.465 & 668 & 91.184 & & \\
Total & & & & & \\
\hline
\end{tabular}

As it is clear in the results summarized in table (5), there were no statistically significant differences at $(\alpha \leq 0.05)$ between the strategies of teachers' professional development due to academic level (Bachelor degree, Master, and $\mathrm{Ph} \mathrm{D})$.

\section{Discussion}

The results showed that conducting action research continually, using social networks (Twitter, Facebook, and others) in exchanging viewpoints and experiences and participating in educational e-forums are the most common strategies of professional development. This result means that EFL and technology teachers still need to pay more efforts for developing their performance and exchange successful experiences.

On the other hand, taking advantages of supervisors' and principle's feedback and participating in discussion groups with colleagues in school strategies scored the lowest level of percentages. The percentages of teachers' responses were (34.814 - 37.148). The researchers attribute this result to the following reasons:

The teachers' concern in conducting action research continually because the supervisors asked them to do action researches and keep them in a portfolio for discussion and evaluation. The supervisors discussed the results of action researches with teachers and invited teachers to exchange their experiences regarding that.

Besides this, teachers rely on social networks as a common strategy of professional development which is due to the widespread use of social networks among Palestinian people in viewing their daily actions and events. Like common people, teachers use social networks to present their daily school events, achievements and problems. Many teachers comment on each others' posts.

In the same context, there are a lot of educational e-forums which present unlimited numbers of activities, instructional aids, games, lesson plans and others. Many teachers access these e-forums and make account on them. Teachers benefit from the available material on developing their practices in the classrooms. In addition, they present their experiences and ask for help when they need it.

Taking advantage of the strategies of supervisors and principals scored the lowest percentages in teachers' professional development strategies which is due to the formal relation among teachers, supervisors and principals. The teachers consider them as monitors for their actions and performance in the classrooms.

The results also indicate that the specialty and academic level variables do not influence teachers' adopting of professional development strategies while the gender variable affects this. The researchers attribute this result to the fact that all teachers work at governmental schools and have the same responsibilities but female teachers always seek to be distinguished in their performance and vary their techniques of teaching. 


\section{Conclusion}

Based on the data of this research study, the researchers reached the fact that, the EFL and technology teachers followed different professional development strategies. Although, they are still in need of enhancement and motivation more to reach the adequate level of adopting professional development strategies. The female teachers are interested more than male teachers in developing themselves professionally.

This research was conducted on EFL and technology teachers only. Further researches need to be conducted on other teachers who are specialized in other subjects.

\section{Recommendations}

In the light of the results, the researchers recommended the following:

- Skillful teachers should establish a system for continuous professional development.

- School teachers are recommended to use the mentioned professional development strategies to keep up with up-to-date information, technology, and professional practices.

- The Ministry of Education is recommended to encourage teachers to build up their own professional development programs by following up these programs, conducting seminars to discuss the successful experiences, devoting a special corner on its website for publishing successful experiences.

- $\quad$ Future studies and suggested programs are still needed for teachers' professional development.

\section{References}

[1] Atwan, A. and Al-Faleet, G. (2010) The Reality of Self Professional Development and its Obstacles among Technology Teachers in Gaza Governorates Schools. Educational Technology and Technological Education Conference, Al-Aqsa University, 27 - 28 October, pp 195 220.

[2] Banks, F. et al (2001) Teacher early Professional Development: the Context. Pp 1 - 10Early Professional Development for Teachers. Frank Banks and Ann Shelton Mayes (editors) TextypeTypesetters:Cambridge.

[3] Baran, B. \&Cagiltay, K. (2006) The Turkish Online Journal of Distance Education. Turkey-DOAJTeachers' Experiences in Online Professional Development Environment, Anadolu University, Eskisehir Volume: 7 Issue: 4 pp: $110-122$.
[4] Diaz-Maggioli, G. (2004) Teacher-Centered Professional Development. ASCD: United Sates.

[5] Granshaw, B. (2010) How Does Teacher Professional Development Support and Improve Technology Teacher Practice?. Victoria University of Wellington, Research Masters Thesis, Retrieved May 30 ${ }^{\text {th }}, 2013$ from http://hdl.handle.net/10063/1582

[6] Halim, S. M. (2008) The Effect of Using some Professional Development Strategies on Improving the Teaching Performance of English Language Student-Teacher at the Faculty of Education, Helwan University in the Light of Pre-service Teacher Standards. Unpublished Ph D, Helwan University: Faculty of Education.

[7] Kesti, L. (2008) Suggested Conception of Self Professional Development for English Language Teachers of girls public schools Based on Realization and Contemporaneous Trends. Unpublished Dissertation, Umm Al-Qura University: Faculty of Education.

[8] Liu, M. (2012) Discussing Teaching Videocases Online: Perspectives of Preservice and Inservice EFL Teachers in Taiwan. Computers and Education, v 59 n 1 p 120 - 133 Aug 2012.

[9] National Staff Development Council. (2001). Standards for Staff Development (Revised Ed). Oxford, Ohio: National Staff Development Council.

[10] De Vries, S. \& van de Grif, J. (2013) Profiling Teachers' Continuing Professional Development and the Relation with their Beliefs about Learning and Teaching.

Teaching and Teacher Education,. Elsevier, Volume: 33 pp: 78-89

[11] Patricia, F. B. and Rhoton, J.(2001) Issues in Science Education: Professional Development: Planning and Design NSTA: The United States of America. Retrieved May $30^{\text {th }}$, 2013 from http://books.google.ps/books?id=BTb52Gs8j3IC\&printsec=f rontcover\&dq $=\% 22$ professional + development $\% 22 \& \mathrm{hl}=$ en $\&$ $\mathrm{sa}=$ X\&ei=rajrUeUkhpA4kZyAmAw\&redir_esc $=y$

[12] Rodrigues, S. (2005a) Model of Teacher Professional Development: The Partnership in Primary Science Project. Nova Science Publishers, Inc: Hauppauge.

[13] Rodrigues, S. (2005b) Teacher Professional Development in Science Education. International Perspectives on Teacher Professional Development, Rodrigues, S. (editor) Nova Science Publishers, Inc. pp. 1- 13

[14] Torff, B.; Sessions, D.; and Byrnes, K. (2005) Assessment of Teachers' Attitudes about Professional Development. Educational and Psychological MeasurementOctober 2005 vol. 65 no. 5 820-830. Retrieved May $30^{\text {th }}, 2013$ from http:/hinari-gw.who.int/whalecomepm.sagepub.com/whalec om $0 /$ content $/ 65 / 5 / 820$ 